\title{
Escândalo ou notícia: os discursos construídos pelas revistas Veja e Carta Capital sobre as denúncias contra o PT e o Governo Lula
}

Scandal or news: the speeches constructed by magazines View and Charter Capital on the accusations against the PT and Lula Government

\author{
DenIS PoRTO Renó \\ Jornalista, mestre e doutorando em Comunicação Social pela \\ Universidade Metodista de São Paulo - Umesp. \\ E-mail: denis@ojosenelmundo.com \\ TÁ́S RIOS SALOMÃO DE SOUZA \\ Rádio e TV, mestre em Comunicação Social pela \\ Universidade Metodista de São Paulo - Umesp. \\ E-mail: trsouza2001@yahoo.com.br
}

\section{Resumo}

0 Brasil assistiu a mais um escândalo político envolvendo representantes do povo, poder e dinheiro. E, mais uma vez, a mídia posicionou-se favorável a um ou outro lado. De certa forma, a mídia foi, novamente, co-responsável pela construção do bandido e do mocinho, utilizando-se de seu poder midiático e de suas ferramentas comunicacionais para exercer esse papel, merecedora de discussão quanto ao seu valor ético e moral. Por esses preceitos, justifica-se o estudo desse artigo, que analisa o papel exercido por duas importantes revistas brasileiras, uma de caráter massivo, populista, e a outra definida como forte formadora de opinião, lida pela elite e por um grupo de pessoas que definem ou redefinem os caminhos da nação, muitas vezes dos bastidores. Trata-se de um olhar crítico ao serviço que os dois recortes midiáticos têm realizado ante a missão majoritária da imprensa: a de informar.

Palavras-chave: Jornalismo, mídia, discurso, imprensa, escândalo político, comunicação.

\section{Introdução}

Entender a mídia é algo fundamental para a sobrevivência da soberania de uma nação. Seu poder é forte, tanto que acabou sendo considerada por muitos como o quarto poder, competindo contra os formais e oficiais poderes executivo, legislativo e judiciário. Mas o quarto poder lança mão de ferramentas nessa briga, pois trabalha com o inconsciente coletivo, com técnicas de comunicação imperceptíveis a olho nu e sem uma análise profunda por parte da grande massa.

Por outro lado, a imprensa exerce um papel fundamental no processo democrático de qualquer nação. Ela é quem dá voz ao povo, fazendo com que a grande massa possa lutar pelos seus ideais, ou então, mantém-o calado, passivo aos acontecimentos. É na imprensa que verdades podem ser informadas e mentiras podem ser reveladas. A imprensa possui uma missão que é lutar pelo povo e com o povo, uma luta sempre pela verdade, o que estudamos neste artigo com pretensões de elucidar a situação referente ao recorte escolhido.

Acontece que cada veículo possui a sua verdade, ideal e ajustada 
aos seus conceitos mais íntimos e pessoais. Desse retrato, surgem as manipulações midiáticas que levam a população a acreditar em algo, a tomar decisões ou partir para atitudes inertes ou ágeis que atendem aos interesses de alguns, de uma pequena parcela, àqueles que querem continuar segurando uma invisível rédea condutora, controladora e manipuladora. Os indivíduos, como é discutido por Thompson (2002), preferem buscar informações e conteúdo simbólico cada vez mais em outras fontes do que nas pessoas com quem interagem diretamente no dia-a-dia.

O Brasil viveu, desde o descobrimento, diversos escândalos, dos mais variados tipos. A nação brasileira pôde assistir a escândalos que envolveram desde comportamentos anti-higiênicos de D. João VI a amantes de D. Pedro I. O país assistiu desde a Tríplice Aliança ao posicionamento de Getúlio Vargas durante a Segunda Guerra Mundial. O cenário brasileiro foi palco para o movimento militar legalista que pôs João Goulart no poder e ao golpe de 64 , quando os mesmos generais tiraram-no do poder.

Em 1989, depois de terem ficado distantes da democracia por 25 anos, os brasileiros elegeram um presidente pelo voto direto, por seu próprio desejo. Não deu certo. A mídia, a mesma que colocou-o no pedestal, modificou o discurso, construindo um escândalo midiático sobre a plataforma política que o mesmo exercia. Histórias foram contadas, denúncias valorizadas, lembranças recuperadas, até que a população tomou partido: a grande maioria pediu o impeachment.

Agora, quase dez anos depois, quando o povo elegeu de forma legítima o seu quarto presidente após os anos de chumbo, surge um novo escândalo político, envolvendo favorecimentos, financiamentos de campanha fora da determinação legal e fatos que ainda ameaçam explodir. E, mais uma vez, a mídia tomou o lugar em que esteve em 1992, quando caras-pintadas foram às ruas para pedir a mudança de governante.

O escândalo não é aceitável, mas natural, quando ocorrido. $\mathrm{O}$ escândalo surge de uma fofoca, de uma denúncia, tomando corpo e chegando à grande massa. Essa, por sua vez, toma partido e exige soluções, descobertas, apurações, até que tudo seja esclarecido e os responsáveis devidamente punidos. Mas, como define Thompson (2002), o escândalo, a certa altura dos acontecimentos, acaba por ser reformado pela mídia, que o valoriza e define os caminhos desejados por uma força oculta, que ocupa um privilegiado espaço dentro do poder: o dos bastidores da nação. Nesse processo, a história passa a ser contada e recontada, valorizando informações que manipulem os desejos de uma nação e construam conceitos e posicionamentos na grande massa. Mas, para que essa construção seja conseguida com êxito, deve-se lançar mão de técnicas fundamentais dentro da linguagem, com ferramentas de discurso nãoverbal e duplas interpretações.

$\mathrm{O}$ artigo analisa as matérias de capa publicadas nas revistas Veja e Carta Capital entre a primeira denúncia envolvendo o ex-tesoureiro do Partido dos Trabalhadores, Delúbio Soares, até a publicação pela revista Veja de uma capa associando claramente o caso Lula ao de Collor, que renunciou após a aprovação do processo de Impeachment, votado durante sessão aberta em 28/08/1992, exigido pela nação em movimentos públicos que levaram às ruas caras-pintadas e gritos de "fora Collor" aos quatro cantos do Brasil. O corpus da 
pesquisa é constituído pelas matérias de capa por sua relevância, pois é essa a informação que o veículo crê ser a de maior importância, senão ao interesse público, ao menos aos interesses da empresa. Como define Pinto (2002):

Utilizar textos na pesquisa social, sem abordá-los como instrumentos lingüísticos ou semiológicos adequados, leva o cientista social com freqüência a só levar em conta o seu valor documental imediato, isto é, a considerá-los inocentemente como "transparentes" em relação ao universo representado, o que significa tratá-los como independentes dos contextos, esquecendo-se sua "opacidade" ideológica, que a análise do discurso coloca em primeiro plano. (PINTO, 2002, p. 29)

Para a análise, foram levantados 11 edições de cada revista, em iguais períodos de publicação. Observouse as técnicas de discurso adotadas e, ao mesmo tempo, analisou-se a adoção desses veículos às normas de ética e conduta definidas dentro do campo jornalístico, que preservam

${ }^{1}$ A montanha dos sete abutres (Ace in the hole), Billy Wilder, 1951, EUA Charles Tatum (Kirk Douglas) é um jornalista sem escrúpulos que vai trabalhar no jornal da pequena cidade de Albuquerque. Ele quer um furo de reportagem que o coloque novamente nos grandes jornais de onde fora banido. A oportunidade surge ao descobrir que Leo Minosa (Richard Benedict), dono de um velho posto de estrada, está preso nas minas da Montanha dos Sete Abutres, um lugar envolto em lendas e mistérios. Essa é a deixa para 0 jornalista transformar um acidente em uma tragédia sensacionalista. Rejeitado pelos jornais da época, o filme se transformou em um grande clássico. Seu enredo, direto e corajoso, é um exemplo muito atual do poder de manipulação dos meios de comunicação em nossas vidas. em seu conteúdo e, obviamente, em seus efeitos. O enredo do escândalo passa a ser tratado como algo importante, incomum, recebe uma valorização e é traduzido de outra, ou de outras formas aos receptores. Surge, então, o escândalo midiático, construído para atender às necessidades da mídia e tendo como fim específico o de aprimorar as vendas dos veículos. Como diz Noblat (2003), a imprensa se aproveita de fatos para transformálos em fatos determinantes que alteram e instigam o desejo humano pelo bizarro, pelo gritante, pelo escandaloso. Como cita o autor:

Infelizmente, estimular os baixos instintos do ser humano, por exemplo, interessa a uma expressiva fatia do público. Aumenta as vendas de um jornal. E amplia a audiência de uma emissora de televisão. Mas proceder assim é condenável porque em vez de contribuir para a elevação dos padrões morais da sociedade, o jornalismo os rebaixa. (NOBLAT, 2003, p. 23)

Mas isso acontece, independente dos efeitos negativos que possam causar no comportamento social. O que importa, invariavelmente, são os efeitos comerciais. E, com isso, o escândalo é levado e alimentado enquanto for possível, garantindo, assim, seus resultados positivos em rentabilidade, como se um novo personagem "Chuck Tatum", protagonista do longa-metragem e clássico "A montanha dos sete abutres" criando e alimentando notícias que poderiam ter menores proporções do que os que foram atingidos.

Isso ocorre graças a uma confusão entre o que é de interesse público e o que é de interesse do público. O jornalismo segue alguns princípios, e um dos mais importante 
refere-se ao que é, realmente, notícia. Para o jornalismo, notícia é, em primeiro lugar, algo de interesse público, o que vai contra um problema construído, o escândalo midiático. Erbolato (2003) discute muito bem a relação entre o que é e o que não é uma notícia. Para o autor, a notícia deve ser recente, inédita, verdadeira, objetiva e de interesse público. Do contrário, não pode ser definida como notícia. Segundo ele:

As notícias são comunicações sobre fatos novos que surgem na luta pela existência do indivíduo e da própria sociedade. A imprensa investe capitais enormes, contrata jornalistas e técnicos dentro de sua área, para a função básica de informar. $O$ noticiário deve ter utilidade pública para os leitores e influenciá-los pessoalmente, mostrando-lhes que devem ter um interesse no assunto divulgado. (ERBOLATO, 2003, p. 52)

Um escândalo é, de fato, uma notícia. Possui interesse público e deve ser divulgado como tal. Porém, quando esse escândalo passa a ser manipulado, alimentado, pautado com o objetivo de manter a vendagem de um editorial, é preciso reavaliar seu valor e sua função. A notícia passa a ser algo desejado e "requentado", manipulando os leitores ao invés de simplesmente influenciá-los. Segundo Ferreira (1999), manipular significa controlar, dominar, enquanto influenciar significa conduzir, convencer. A manipulação é cruel, enquanto a influência é, de certa forma, suave. E, apesar de ainda possuir méritos, seus resultados passam a merecer atenção quanto suas finalidades, se sociais ou societárias. Quando isso acontece, o que era de interesse público passa a ser de interesse de uma minoria dominante, com suas vaidades e seus desejos de poder e riqueza. Claro que uma empresa de comunicação possui interesses particulares relacionados à riqueza e, de certa forma, ao poder. Mas isso não deveria ser motivo para manipular através de uma informação. O jornalismo não deve se prender a interesses particulares, e sim somente aos interesses públicos, alimentando a sociedade do que ela realmente precisa: de uma verdadeira e confiável informação. Mas isso, na realidade, não acontece. Como é definido por Dijk (2003):
As ideologias profissionais e sociais (sexo, etnia, classe, idade, etc.) dos jornalistas controlam a quem se investi- gará, cobrirá, escutará ou entrevistará. Portanto, a infini- dade de atividades que definem as notícias de cada dia e a realização de um jornal diário ou programa de televisão se baseia nas ideologias dos atores sociais que participam como membros de grupos sociais diferentes. (DIJK, 2003, p.43).

Como avalia Thompson (2002), o discurso passa, inevitavelmente, por uma transformação. Uma transformação que atenda aos interesses e que possa manter a procura do veículo por mais tempo. E quando essa informação perder o crédito, o que ocorre, fatalmente, cria-se outro escândalo, e mais outro, sucessivamente.

$\mathrm{O}$ autor defende a existência praticamente constituída de uma maneira de se construir o escândalo midiático. Para ele, tudo nasce de um escândalo, que é alimentado, aquecido, repetido, até que é preciso antever um "futuro". Para ele:

Os escândalos midiáticos
normalmente se desenrolampor
um período de tempo que é
marcado pelos ritmos das
organizações da midia, com seus 
padrões distintos de publicação e difusão. Eles mostram também certa estrutura seqüencial, no sentido que uma fase no desenrolar dos escândalos midiáticos é previsivelmente seguida por outra. E o desdobramento dos escândalos midiáticos é entrelaçado por um constante recontar histórias sobre os acontecimentos (ou supostos acontecimentos) presentes no centro do escândalo. (THOMPSON, 2002, p.102).

Em seguida, quando os acusados recebem o direito de resposta, inevitavelmente vão negar, criando no público uma dúvida quanto à veracidade do escândalo midiático. Então, a imprensa cria um novo escândalo, desviando temporariamente a atenção ao escândalo midiático principal.

\section{Os indivíduos colocados no centro do escândalo podem convencer-se de que se eles negarem firme e repetidamente seu envolvimento nas atividades alegadas e se eles puderem (caso seja necessário) trancar qualquer vazamento e prevenir toda evidência de incriminação emergente, então o público irá certamente se cansar de uma história que cada vez mais parece forjada. (THOMPSON, 2002,p.105).}

Os escândalos se repetem, sucessivamente, através de histórias semelhantes, e isso faz com que a mídia, como num esforço final, tente comparar o passado com o futuro. Dessa forma, o calor da discussão perdura por mais tempo, mantendo ainda mais o faturamento que acontecimentos como este, que envolvem uma nação e mexem com um prazer humano pelo escandaloso, possibilitando ainda mais o alcance dos resultados esperados.

\section{Os construtores de escândalos}

Cada veículo possui seus interesses, que podem resultar em histórias e visões diferenciadas. E, em meio a uma realidade específica e de interesse, constroem noticias e escândalos com diferentes pontos de vista, e de acordo com o seu público.

(...) cabe, ainda fazer as distinções complementares relativas ao momento de seu consumo, também presentes em todo texto. Ao autor empírico corresponde o seu público ou audiência (ouvintes, leitores, espectadores, etc.), que são os indivíduos de carne e osso a quem caberá interpretar o texto produzido. (PINTO, 2002, p. 35).

Um dos construtores analisados no trabalho em questão é a revista Veja. Dirigida à grande massa, a Veja possui tradição e credibilidade históricas. Envolveu-se em momentos importantes do passado político brasileiro, como a campanha das "Diretas Já". Esteve à frente de denúncias marcantes, como as revelações de Pedro Collor de Melo sobre detalhes das vidas pública e particular de seu irmão, o expresidente Fernando Collor de Melo, publicadas em 13 de maio de 1992, criando, assim, um escândalo político que se tornou midiático.

Do outro lado da análise, tem-se a revista Carta Capital, que possui uma história de vida um pouco menor, apesar da imagem do jornalista Mino Carta acompanhar o editorial. Carta participou ativamente de movimentos contra os anos de chumbo, estando ao lado de jornalistas que marcaram a história, como Vladimir Herzog e Rodolfo Konder. Porém, a revista também segue o exemplo da colega mais velha, possuindo um posicionamento político. Mas, inversamente ao posicionamento da Veja, a Carta 
Capital é declaradamente a favor do Governo Lula.

Isso se mostra claro quando se analisa detalhadamente o recorte em questão, onde pode ser percebida uma exacerbada adoção de adjetivos nas matérias contra de um lado e a favor do Governo Lula de outro. Ambas as empresas de comunicação tentam construir conceitos de certa forma defendidos por Erbolato (2003). Porém, da forma com que estimulam o pensar e o agir, tornamse cúmplices de um resultado plantado e colhido, tornando-o irreal e fraudulento

Pressupostos teóricos e metodológicos

A leitura comparativa dos textos foi subsidiada pelos estudos da linguagem, como fator de interação social e pelas teorias do discurso, mais especificamente da linha francesa. Essa não se basta pela análise textual, isto é, mesmo sendo este o material empírico deste trabalho, a análise deve compreender o processo de produção do texto, seu contexto e historicidade, caso contrário o discurso midiático pode ser interpretado de forma acrítica e até equivocadamente. Assim, buscou-se verificar no texto, além do seu sentido literal e denotativo, também a sua "historicidade, o que significa se colocar no interior de uma relação de confronto de sentidos"(BACEGGA, 1998, p. 91).

O confronto de sentidos é nítido no episódio em questão, tanto quanto sua historicidade dentro do contexto político do país, seja por haver um governo petista no poder, seja pelo paradoxo entre a ideologia do partido e os procedimentos eticamente condenáveis nos quais seus líderes estão envolvidos.

Diante do objetivo proposto, foram observadas e interpretadas matérias de capa de 22 edições (11 da revista Veja e 11 da revista Carta Capital), correspondendo às matérias de capa publicadas entre a denúncia do ex-deputado federal Roberto Jefferson e a saída do exminsitro da Casa Civil, José Dirceu, durante o período de denúncias do Governo Lula conhecido como crise do mensalão, iniciada com a CPI dos Correios.

Buscou-se identificar na análise dos textos os sentidos explícitos e implícitos, ou seja, a intencionalidade presente na construção da mensagem. Por tratar de intencionalidade parte-se do pressuposto apresentado por Santaella (1996) de que as linguagens não inocentes nem inconseqüentes. Para a autora há uma íntima relação entre linguagem e ideologia, o que se torna mais evidente em: As linguagens que dão corpo às
ideologias, na dimensão de
cada cultura historicamente
determinada, trazem inevitavel-
mente as marcas da posição
política dos agentes sociais. A
linguagem que falamos, o
sistema de sinais que emitimos,
a miríade de traços, escolhas,
omissões e partilhas de que
somos compostos falam de nós.
São indicadores de nossa
posição peculiar na rede tensa
das tendências políticas.
(SANTAELLA, 1996, p. 331)

A partir desta perspectiva de linguagem pode-se avançar para um outro conceito que é o de realidade e como este se relaciona com o primeiro. Sabendo a carga ideológica presente em qualquer linguagem entende-se que a realidade será descrita, ou melhor, refratada, cada vez que for mencionada. Sabendo a carga ideológica presente em qualquer linguagem, entende-se que parte da realidade será descrita, ou 
melhor, refratada, cada vez que for mencionada. Por mais completa que possa ser a notícia, do ponto de vista do volume de informações, ela nunca conseguirá reproduzir o fato real, com todas as suas nuances, mas será apenas um recorte da realidade. A leitura das reportagens enfatizou a matéria de capa de cada uma das edições que compõem o corpus da pesquisa, identificando a presença do assunto em questão - crise no governo - frente aos demais assuntos abordados na revista.

Como elemento de análise, observou-se a escolha lexical, principalmente nas manchetes, o uso de adjetivos, fato que no campo jornalístico é discutível e, muitas vezes, condenável, os personagens envolvidos além da forma como a reportagem é estruturada.

Vale ressaltar que se trata de uma pesquisa qualitativa, portanto a quantificação do espaço ocupado na página ou na edição só foi mencionada quando relevante para determinada consideração qualitativa e comparativa.

A análise crítica do discurso, neste contexto de leitura comparativa, contribui ainda ao considerar o silêncio como elemento importante a ser observado. Neste caso, o fato de uma revista explicitar um dado e omitir outro pode ser relevante para a análise. Sobre isso, Orlandi (1996, p.493) esclarece que "não se pode traduzir o silêncio em palavras sem modificá-lo, pois a matéria significante do silêncio significa por si mesmo, ou seja, o silêncio não fala, ele significa". O resultado é, inevitavelmente, uma parcialidade de informação não indicada para a prática jornalística.

Implícito e explícito de um escândalo midiático

Em um jornal impresso entende- se que a primeira página seja como um retrato datado do que foi considerado notícia, um recorte que segue os padrões editoriais e define o que será realidade ou que ênfase lhe será conferida. Para uma revista semanal este retrato é composto, principalmente da matéria de capa, que indica parâmetros significativos, mas não absolutos sobre o posicionamento do veículo comunicacional frente à temática, sendo necessário recorrer à estrutura da revista para uma análise mais completa.

A 'profundidade da leitura' do texto não depende tanto da amplitude dos conhecimentos, nem do grau de adequação do sujeito. Não se correlaciona indefectivelmente com a análise lógica do sistema superficial de significados, senão que depende principalmente da sensibilidade emocional do sujeito, mais do que de seu intelecto formal. (LURIA, 2001, p.197).

Uma primeira leitura do corpus aponta traços naturais da evolução de um escândalo midiático, por isso as revistas foram agrupadas em três períodos que possibilitaram uma análise mais aprofundada da criação deste escândalo, suas etapas, personagens e o posicionamento do veículo comunicacional. É importante dizer que os períodos foram determinados a partir da observação das revistas e dos acontecimentos que registravam.

O primeiro elemento que se destaca para a análise é o conteúdo das matérias. Observa-se o período delimitado pelas quatro primeiras publicações, quando ambas as revistas adotaram certa cautela no que se refere a afirmações a respeito das denúncias. Percebe-se que, neste momento, apesar de estar se armando um escândalo midiático, ele 
anda estava sendo tratado pelas publicações como simplesmente político. As acusações eram transferidas cuidadosamente para as fontes, buscando uma sutileza na escolha do lado, no posicionamento parcial. Mas, apesar de tanto cuidado, ambas as revistas já começavam a exacerbar na adjetivação das matérias, utilizando-se de ironias para se dirigir aos personagens envolvidos, como é notado nos trechos das reportagens de Veja de 01/06/2005, pág.48 e Carta Capital de 01/06/ 2005, pág. 26, respectivamente:

"Em seu esforço para impedir a criação da CPI dos Correios, o Palácio do Planalto apelou para o arsenal típico do presidencialismo brasileiro: ameaças, cargos e dinheiro. Um recurso em particular, no entanto, chamou a atenção: as súplicas dirigidas ao presidente do PTB, o deputado Roberto Jefferson, aquele que diminuiu o estômago mas cujo apetite aumentou" e "O PSDB aproveita a CPI dos Correios, sobe o tom dos ataques e oferece um 'gerente' como candidato à Presidência".

Além disso, uma forte manipulação pode ser encontrada nas edições de Veja e Carta Capital, ambas de 3 de agosto de 2005, quando atacam posições contrárias. A Veja declara logo no primeira parágrafo que o "ex-todo-poderoso ministro-chefe da Casa Civil, deputado José Dirceu", e logo no final da mesma página cita-o novamente, dizendo que "ele foi responsável pela construção do PT nos moldes que se conhece, promovendo figuras virtuosas como José Genoíno, Delúbio Soares, Silvio Pereira e Marcelo Sereno", atacando em 22 páginas apenas o PT. A revista Carta Capital, por sua vez, mira suas palavras na oposição, declarando em diversos momentos das dez páginas que abordam o tema que tanto o PSDB quanto o PFL foram os criadores do mensalão. $\mathrm{Na}$ matéria, tal intenção fica clara na página 30 , quando o subtítulo do texto diz que "as investigações mostram que tucanos e pefelistas usaram o mesmo esquema".

Ainda que a adjetivação e a ironia sejam recursos lingüísticos para denotar o sentido dado à determinada situação ou personagem é importante ressaltar, no entanto, que a postura praticada em cada veículo é determinada, antes de tudo, pela ideologia vigente na empresa comunicacional.

A ideologia que permeia cada órgão midiático direciona, entre outros aspectos, a escolha da pauta, dos personagens, das fontes escolhidas e, principalmente, do recorte feito no assunto abordado.

Quanto ao objeto de pesquisa, a escolha de recortes distintos fica evidente nas manchetes das duas primeiras reportagens analisadas de cada uma das revistas: Veja de 01/ 06/2005 e de 08/06/2005. "O que será que ele sabe?" e "Lutar contra a corrupção já é uma vitória" e Carta Capital de 01/06/2005 e de 08/06/ 2005 "Palanque tucano" e "Juros freiam o Brasil real". Percebe-se que a ênfase dada à crise é diferente nos dois periódicos. $\mathrm{Na}$ primeira manchete de Veja, a pergunta retórica só consegue completar seu sentido por estar sobreposta a imagem que relaciona um tapete $\mathrm{e}$ uma vassoura com o símbolo do PT ao deputado Roberto Jefferson. Da mesma forma, a segunda manchete também se utiliza da imagem, no caso a bandeira nacional rasgada, para enfatizar seu sentido. A corrupção foi o aspecto da crise resgatado pelas manchetes de Veja. O periódico Carta Capital, no 
entanto, parece relacionar a crise política a outros aspectos, a princípio, fora do centro da questão como o posicionamento da oposição e a situação econômica do país.

Diante de abordagens diferentes cabe uma breve reflexão sobre como a prática ideológica de determinado meio age sobre princípios jornalísticos como interesse público e atualidade. A ausência nas manchetes e reportagens dos personagens conhecidos e evidenciados pelos vários tipos de mídia conduz o leitor a outras prioridades. Para Dijk (2003, p.48) "isso significa que o discurso poderoso pode influenciar em como definimos um acontecimento ou uma situação nos nossos modelos mentais, ou em como representamos a sociedade no nosso conhecimento, atitudes e ideologias".

Charaudeau (2003, p.15) complementa este raciocínio com uma observação sobre o papel desempenhado pelos meios no processo comunicacional: "os meios não transmitem o que ocorre na realidade social, já que impõem o que constroem do espaço público. A informação é essencialmente uma questão de linguagem, e a linguagem não é transparente".

Com a evolução do tema (delimitado entre a quinta revista e a oitava da série), a linguagem passou a pender para uma ampla utilização dos adjetivos: estava dado início ao processo de escândalo midiático, marcado por uma guerra ideológica entre ambas as revistas. Enquanto a Veja assumia uma posição favorável à oposição, protecionista dos envolvidos do PSDB, a Carta Capital apoiava-se fortemente na defesa do Governo Lula e parte de seus partidários envolvidos.

"As denúncias explosivas do deputado Roberto Jefferson, o homem-bomba do PTB...", na Veja de 01/06/2005, pág. 54. A expressão homem-bomba é usada como forma de reforçar a idéia de que há muito a se descobrir envolvendo o Governo Federal - enfatiza a figura do homem revelador, polêmico e sem papas na língua, o homem-bomba o que acaba por valorizar ainda mais as declarações do deputado citado. $\mathrm{Na}$ maior parte do texto o passado político do então deputado Roberto Jefferson (que fez parte da base apoio do ex-presidente Collor), bem como as denúncias de corrupção feitas em 2005 envolvendo Jefferson e um funcionário dos Correios, praticamente são deixadas de lado pela revista. Uma forma de dar credibilidade ao denunciante e ao mesmo tempo enfatizar suas acusações.

"A reação de Lula foi o bastante para enfezar ainda mais o animo radicalizado dos tucanos. Um deles, o deputado Eduardo Paes, ao abrir o bico com raiva, resolveu uma das diferenças entre as aves e os homens: 'Deu-nos um gosto de sangue na boca'.", na Carta Capital de 01/06/2005, pág. 34. Aqui, a revista deixa clara sua postura de apoiar o governo Lula e ironizar várias ações da oposição. Expressões como "ira da oposição", "enredar o presidente Lula" e "show pessoal de Jefferson", na Carta Capital de 01/06/2005, pág. 34, são exploradas com o intuito de menosprezar as ações de oposição como algo gratuito, aleatório e ainda garantir uma certa defesa pública do Governo Federal enquanto uma ação midiática.

Mas, apesar de ambas as revistas tomarem, nesta fase, semelhantes condutas, diferenças marcantes podem ser percebidas entre elas. A Veja, sem assumir seu posicionamento, passou a manipular de forma suprema o conteúdo publicado. Nas páginas da revista, apenas os governistas eram os 
bandidos, mesmo quando surgiram denúncias de candidatos tucanos de Minas Gerais. As frases ditas pelos oposicionistas eram publicadas, contanto que não denegrissem a imagem do processo de escândalo midiático armado. Ao mesmo tempo, a Carta Capital adotava, sem piedade, a utilização de adjetivos irônicos para falar dos envolvidos e dos oposicionistas. Termos adotados de forma freqüente, como o Valerioduto (para tratar do esquema de distribuição de dinheiro criado por Marcos Valério), ou o orelhudo (quando se fala do banqueiro Daniel Dantas), passaram a ilustrar capas e títulos de matérias. "Não seria surpresa se, ao longo das apurações, à CPI dos Correios e a Polícia Federal encontrassem elos entre a secretária e a maior disputa societária da história do capitalismo nativo - a briga entre o banqueiro Daniel Dantas, dono do Grupo Opportunity, e os fundos de pensão". (Carta Capital 08/06/ 2005 , p. 28). Nesse momento, a revista Carta Capital faz uma crítica à própria atuação da imprensa nacional mostrando que a mídia novamente procura por único personagem capaz de dar um desfecho a toda crise política como o motorista Eriberto França, que ligou a Casa da Dinda ao esquema PC Farias e viabilizou a cassação de Fernando Collor. O banqueiro Daniel Dantas além de ser destaque na reportagem de Carta Capital é também ridicularizado e apontado como criminoso. "Até então tratado como um empresário polêmico, Dantas passou a carregar a imagem de criminoso. Em maio deste ano, a Justiça Federal o indiciou por formação de quadrilha”. Carta Capital de 08/06/2005, pág. 31. A revista Carta Capital adota uma postura de aprofundar as discussões sobre a crise e trazer novos elementos que justificariam o interesse da ex-secretária de Marcos Valério Fernandes de Souza, Fernanda Karina Somaggio, em procurar a revista IstoÉ para fazer as denúncias do pagamento do mensalão.A briga, com direito a troca de acusações, entre IstoÉ e Veja também merece atenção da revista Carta Capital.

Ao mesmo tempo, a revista editada por Mino Carta passou a dar voz às declarações dos oposicionistas que pudessem comprometer o processo, como a que o expresidente Fernando Henrique Cardoso disse, ao ser indagado sobre o desejo do PT de ampliar a quebra de sigilo de cinco para dez anos, disse que o que aconteceu em seu governo ficou para a história. Neste caso, a Carta Capital deu espaço de diálogo textual entre Fernando Henrique e Tarso Genro, quando o então presidente interino do Partido dos Trabalhadores disse que isso era um protecionismo de FHC aos problemas de sua gestão. Estava sendo conduzido o escândalo midiático, sendo gradativamente alimentado pelos dois veículos de acordo com a condução do caso.

A terceira e última fase analisada pode ser percebida como a decadente do processo midiático que a imprensa sofria. Com fatos esgotados, a revista Veja apelou para matérias extremamente manipuladoras. Nesta fase, a revista utilizou adjetivos com intensidade, ampliou o posicionamento tendencioso adotado desde o começo, passando a assumilo sem limites, aplicou nos textos frases e termos que pudessem conduzir os leitores a assumir posicionamentos e ainda aliciou-os a organizar o impeachment do presidente Lula, como pôde ser observado principalmente nas duas últimas. Na penúltima, quando o tema discutido é José Dirceu, a Veja 
utilizou-se de fotografias manipuladas em recursos computacionais para transparecer que o então deputado federal possuía um lado ainda na obscuridade, utilizando-se de uma linguagem não-verbal sobre Dirceu. Para Orlandi (1996), o nãoverbal ganha vida e possui poder para provocar reações. Para o autor:

Não se pode traduzir o silêncio em palavras sem modificá-lo, pois a matéria significante do silêncio e a das palavras diferem: além disso, o silêncio significa por si mesmo, ou seja, o silêncio não fala, ele significa. A partir dai desenvolvo toda uma reflexão para mostrar que há um ritmo no significar que supõe o movimento entre silêncio e palavras, entre silêncio e linguagens. (ORLANDI, 1996, p.463).

No mesmo período, a Carta Capital adota a conduta protecionista aos envolvidos, tentando, porém, preservar apenas o presidente Lula e o ministro da Fazenda daquele período, Antonio Palocci, dos ataques. Para isso, continuou adotando adjetivos irônicos aos adversários governamentais, mantendo Delúbio e Valério no centro das discussões, sempre resgatando os envolvimentos dos tucanos na crise do mensalão. Nessa fase, a Carta Capital adota efeitos de edição de imagens para construir personagens para combater os ataques armados pela Veja aos governistas.

Na edição do dia 22 de junho de 2005 a revista Carta Capital explora uma foto de Roberto Jefferson - em meia página -, em pose teatral em contraposição a foto de José Dirceu - que ocupa uma página inteira -, com ar de preocupação com olhos fechados e mão sobre a testa. "Mas", "talvez", "quase", "mesmo" e "até quando" estão em destaque na revista Carta Capital de 08/06/2005, pág.26. Neste caso, os operadores argumentativos reforçam detalhes do texto e da fala dos entrevistados na reportagem intitulada "Sob Fogo Cerrado" que desqualifica o acusador Roberto Jefferson e destaca a saída do então ministro José Dirceu da Casa Civil.

O ponto culminante do período analisado é percebido na última revista analisada, quando a Veja adota uma estratégia final, ou tudo ou nada, apostando todas as suas forças num exemplar que traz na matéria de capa uma declarada propaganda ideológica. É publicado na mais nobre editoria de uma revista algo que ocupa apenas quatro páginas, aproveitando-se apenas do poder de chamar a atenção do leitor e colocando efeitos de tratamento visual. Como é discutido e analisado por Pinto (2002), é comum a utilização de recursos de reconstruções de conceitos em revistas. Segundo ele:

\section{A mídia impressa, em especial nas capas de revistas e na primeira página dos jornais, utiliza diversas técnicas de tratamento de imagens $e$ diagramação para definirem posições enunciativas. (PINTO, 2002, p. 39).}

Em seu conteúdo, nada além de um resgate histórico a respeito do processo de impeachment do expresidente Fernando Collor de Melo e um breve manual de como se dá início a um processo de perda de mandato de um presidente da república. O mais intrigante é que, além de trazer na capa o nome Lula com duas letras L, como Collor, ambas são escritas da mesma forma que o ex-presidente adotara em sua campanha, em verde e amarelo. Tudo isso num período em que outras 
empresas importantes de comunicação do país, como a Rede Globo de Televisão, abriam um espaço nunca visto desde que Collor saiu do poder, simultaneamente à capa da Veja. Sobre este ponto Dijk (2002, p.158) colabora com a reflexão de que "O leitor é geralmente capaz, possivelmente através de sinais de implicitude no texto, de recuperar tais "elos" faltantes. Isto mostra que os modelos são relevantes tanto na compreensão como na produção de discurso". Assim, a reprodução de formatos já conhecidos do leitor elucidam a análise acerca das noções de intenção e sentido pretendido.

O que ocorreria naquele momento podia ser algo inofensivo, se levado em conta apenas o instante. Porém, uma informação não deve ser interpretada como algo imediato, isolado. Como define Luria (2001):

\section{As frases não são elos isolados de uma cadeia única: cada frase 'influi' ou inclui em si o sentido da anterior; este fenômeno, que L. S. Vigotski denominou 'influência' ou 'incorporação' (fusão) dos sentidos, exerce uma influência substancial na compreensão do conteúdo fundamental do texto. (LURIA, 2001,p. 189).}

Diante de tal conduta, a Carta Capital adota uma postura mais discreta, ao mesmo tempo em que seus adjetivos continuam sendo usados. Na edição do mesmo período, 10 de agosto de 2005, a Carta Capital trata de atacar com parcimônia o PSDB num suspiro final para mostrar o envolvimento do partido oposicionista no mesmo esquema, mas em tempos anteriores. Nessa matéria, na página 29 , a revista envolve através de um Box de quase uma página o ex-tesoureiro tucano Ricardo Sérgio no esquema de corrupção e do chamado
Valerioduto. Vale observar que a Carta Capital não deixou de utilizar seus adjetivos irônicos neste instante. Apenas tornaram-se inofensivos, se comparados à conduta adotada pela Veja naquela semana.

\section{Conclusão}

Os fatos que sucederam o escândalo envolvendo a cúpula do PT com fraudes, mensalões, acordos políticos e pagamentos em paraísos fiscais provocaram na mídia uma disposição para construir um escândalo midiático, conforme as "previsões" de Thompson.

O começo do processo teve um período marcante, que pode ser percebido logo após as denúncias do ex-deputado federal Roberto Jefferson envolvendo o extesoureiro do Partido dos Trabalhadores, Delúbio Soares, e o ex-chefe da Casa Civil, José Dirceu. Naquele momento, tanto a Veja quanto a Carta Capital mantiveram uma certa reserva. Afinal, o escândalo ainda estava em seu princípio de construção.

Com o tempo, o escândalo passou a ser montado, transformando-se rapidamente em um escândalo midiático, com intensa participação das "notícias" em sua consolidação. Na realidade, percebeu-se uma revista Veja tentando construir um escândalo midiático que enfraquecesse e conduzisse a opinião pública para uma condenação do governo petista. Para isso, utilizou-se um grande número de adjetivos, dando ao texto um toque opinativo indesejado naquele tipo de matéria.

Do outro lado, percebeu-se a revista Carta Capital como defensora do PT, tentando, mesmo que de forma mais sutil, construir um escândalo que rompesse fronteiras partidárias e mostrasse que $\mathrm{o}$ 
problema não se limita ao Partido dos Trabalhadores, e sim pode ser detectado em todos os outros, inclusive no PSDB, seu maior opositor. Adotou-se como regra a utilização de adjetivos, como percebido na Veja, fortalecendo ainda mais a manipulação midiática.

Enquanto o combate estava dentro do campo dos textos opinativos e manipuladores, podia-se perceber um discurso aberto, que mostrasse claramente as intenções dos emissores. Porém, quando a Veja publicou a última capa analisada, surgiu uma nova técnica de manipulação de opiniões dentro do processo, utilizando um intenso arsenal de linguagens implícitas. Naquele instante do escândalo midiático, a revista passou a informar sem ter o que falar, tentando provocar uma opinião pública.

A Veja, utilizando-se de símbolos que transportavam o leitor aos tempos do impeachment de Fernando Collor de Melo, como o nome Lula escrito com as mesmas fontes e com duas letras L, sendo uma em verde e outra em amarela, igualmente usada pelo ex-presidente no fim da década de 80 , durante sua candidatura, tentou construir uma relação entre os dois presidentes. Nos textos também percebeu-se o desejo pela relação histórica entre os dois candidatos. Foram quatro páginas, não contabilizando a capa, sem notícia alguma. O único objetivo percebido nas linhas daquela matéria foi o de ensinar o leitor a pedir impeachment de forma democrática e dentro da Lei.

Percebe-se com clareza os interesses da Veja ao defender seus interesses, sem se preocupar com as condutas jornalísticas. Por outro lado, pode-se observar que a Carta Capital, acostumada a "falar" com determinada faixa social, adotara uma linguagem mais amena, se comparada à apresentado pela Veja.

Enfim, percebe-se com a pesquisa que o escândalo político que envolveu integrantes do governo Lula tornou-se rapidamente midiático, sustentando inúmeras semanas de vendagem das publicações, e conseguiu, de quebra, comprometer o futuro da reeleição do então presidente da República. Outra característica desse evento é um certo desinteresse do público pelo escândalo político midiático a partir de um dado momento, que pode ser gerado pelo prolongado tempo de exposição do fato em praticamente todos os grandes veículos de comunicação. Como descrito por Thompson (2001), o escândalo publicado nas revistas analisadas segue as etapas esperadas, e pode ser percebido com mais clareza se observados os acontecimentos seqüentes. $\mathrm{O}$ que deve-se lamentar é a construção midiática deste escândalo político sem analisar as conseqüências graves que tal interesse particular pode provocar à estabilidade do país. De fato, o que o Brasil assistiu foi à reconstrução desse escândalo midiático, que atende aos interesses dos dois veículos, cada um com sua versão da história, alimentando um futuro idealizado e influenciando nos atos da grande massa.

\section{Abstract}

Brazil saw a further scandal involving political representatives of the people, power and money. And, once again, the media positioned themselves in favour of either side. In some ways, the media was, again, co-responsible for the construction of the villain and the mocinho, using their power mediatic and their communication tools to carry out this role, worthy of discussion on its ethical and moral value. For these precepts, it is the study of this article, which examines the role exercised by two important Brazilian journals, a massive character, populist, and the other defined as strong forming of opinion, read by the first class and for a group of people that define or 
redefine the ways of the nation, often the scenes. This is a critical look at the service that the two media clippings have done before the mission majority of the press: to inform.

Keyword: Journalism, media, speech, press, political scandal, communication.

\section{Referências}

BACCEGA, M. A. Comunicação e LinguagemDiscursos e Ciência. São Paulo: Moderna, 1998.

CHARAUDEAU, Patrick. El discurso de la información: la construcción del espejo social. Barcelona. Gedisa editorial, 2003.

DIJK, Teun A. Van. Ideologia y Discurso. Barcelona: Ariel, 2003

DIJK, Teun Adriano Van. Cognição, Discurso e Interação. São Paulo: Contexto, 4. ed., 2002.

ERBOLATO, Mário L. Técnicas de codificação em jornalismo. 5. ed. São Paulo: Ática, 2003.

FERREIRA, Aurélio Buarque de Holanda. Novo Aurélio Século XXI: o dicionário da língua portuguesa / Aurélio Buarque de Holanda Ferreira
- 3. ed. Rio de Janeiro: Nova Fronteira, 1999.

LURIA, Alexander Romanovich; trad. Diana Myriam Lichtenstein e Mário Corso; supervisão de trad. Sérgio Spritzer. Pensamento e Linguagem. Porto Alegre: artes Médicas, 2001.

NOBLAT, Ricardo. A arte de fazer um jornal diário. 3. ed. São Paulo: Contexto, 2003.

ORLANDI, Eni Puccinelli. In MAGALHÃES, Maria Izabel Santos (Org.). As múltiplas faces da linguagem. Brasília: Ed. UnB, 1996.

PINTO, Milton José. Comunicação e Discurso: Introdução à análise de discursos. São Paulo: Hacker Editores, $2^{\text {a }}$ ed., 2002.

SANTAELLA, L. Produção de linguagem e ideologia. São Paulo: Cortez, 1996.

THOMPSON, John. O escândalo político: o poder e visibilidade na era da mídia. Petrópolis: Vozes, 2002.

THOMPSON, John. A Mídia e a Modernidade:uma história social da mídia. Petrópolis: Vozes, 6. ed., 2004. 